Institute for Research on Poverty

Discussion Paper no. 1143-97

\title{
The Changing Economic Status of Disabled Women, 1982-1991: Trends and Their Determinants
}

\author{
Robert Haveman \\ Department of Economics and La Follette Institute of Public Affairs \\ University of Wisconsin-Madison \\ Karen Holden \\ La Follette Institute of Public Affairs and Department of Consumer Science \\ University of Wisconsin-Madison \\ Barbara Wolfe \\ Department of Economics and Preventive Medicine \\ University of Wisconsin-Madison \\ Paul Smith \\ Office of Tax Analysis \\ Department of the Treasury \\ Kathryn Wilson \\ Department of Economics \\ Kent State University
}

September 1997

This paper is a revised version of one prepared for presentation at the 1997 Annual Meetings of the American Economic Association. This research was partially supported by a grant from the Social Security Administration. Conclusions represent those of the authors alone and not of the funding agency.

IRP publications (discussion papers, special reports, and the newsletter Focus) are now available electronically. The IRP Web Site can be accessed at the following address: http://www.ssc.wisc.edu/irp/ 


\begin{abstract}
This study provides an assessment of the intertemporal economic well-being of a representative sample of women who began receiving Social Security Disability Insurance (SSDI) in 1980-81. We compare their economic circumstances over the 1982-1991 period with those of disabled men who also began receiving SSDI in those years and with those of a matched sample of nondisabled women who had sufficient work experience for benefit eligibility should they have become disabled. In 1982, the new SSDI women beneficiaries were a relatively poor segment of U.S. society: one quarter of them lived in poverty and 48 percent had incomes below 150 percent of the poverty line. As of 1991, over one-half of these disabled women lived in families with income below 150 percent of the poverty line. Social Security benefits to disabled women have played an important, and growing, role in sustaining economic status. Nevertheless, the level of well-being of these women lies substantially below that of the comparison groups. We statistically relate the poverty status of these new female recipients to sociodemographic factors that would be expected to contribute to lower levels of well-being, and we simulate the effect of Social Security benefits in reducing poverty and replacing earnings. We suggest a number of SSDI-related policy changes that could, at low cost, reduce poverty among the poorest women.
\end{abstract}




\section{The Changing Economic Status of Disabled Women, 1982-1991: Trends and Their Determinants}

As women's work patterns have approached those of men, their contact with and treatment by the nation's social insurance system have also changed. Women are now more likely than in prior years to be eligible for benefits from the Social Security Disability Insurance (SSDI) program on their own account, as many of them have an established work record beyond the minimum necessary for eligibility (Rupp and Stapleton, 1995). However, in part because of lower wage rates and a higher prevalence of part-time and intermittent work (Blau and Ferber, 1986; Buckley, 1971; Groshen, 1991), benefit levels for disabled women lie below those for disabled men (Social Security Administration, 1996). Hence, while Social Security coverage has increased for women, for many of them the system still provides only a small cushion against earnings loss because of disability, contributing to the growth in the share of women eligible for means-tested benefits from Supplemental Security Income who are also SSDI recipients (Rupp and Stapleton, 1995). The reflection of labor earnings disparities in income disparities subsequent to disability-induced work cessation results in higher poverty rates among disabled women than among disabled men. This higher risk of poverty due to women's different earnings histories may be either offset or reinforced by the marital status differences between women and men who are disabled (Kearney et al., 1995). It will be reinforced to the extent that women with disabilities are more likely either to not be married or to have spouses with relatively low earnings capacity. It will be offset to the extent that husbands of women with disabilities compensate for their wives' work limitations by increasing their own work effort, earnings, and hence contributions to family income.

The 1982 New Beneficiary Survey of the Social Security Administration provides a reliable basis for studying the comparative patterns of men and women receiving benefits from SSDI (Social Security Administration, 1993). Should hypotheses about the sources of economic disparity between the families of disabled men and women be supported in the data, policy makers may wish to reconsider the structure 
of the Social Security program relative to its objectives: should social insurance be designed primarily to reduce earnings uncertainties associated with disabilities (and hence strictly tied to replacing lost earnings), or should it serve as a broader safety net for those with more limited histories of labor force participation ${ }^{1}$

Here, we estimate the level of economic well-being for the population of women who began receiving SSDI benefits in 1980-81 and describe the trend in their well-being over the subsequent decade. Because this SSDI population is a subset—and by some estimates a minority—of the workingage population with functional limitations (Mashaw and Reno, 1996), our results apply to women whose work limitations are sufficiently severe to establish eligibility for earnings-replacement cash benefits from SSDI, but not to all women with health limitations.

We begin by describing the data base with which we work and then compare the characteristics of this group of disabled women with those of a similarly defined group of disabled men and of a group of nondisabled women with sufficient work histories to be eligible for SSDI should they become unable to engage in substantial gainful employment. We then study comparative trends in well-being among these groups over time, focusing on the prevalence of poverty and its correlates. We conclude by describing the effectiveness of Social Security income support in reducing poverty for this group of disabled women and the comparison groups.

${ }^{1}$ This of course is tied to the broader issue of the conflicting pillars of social insurance: social adequacy and individual equity. 


\section{DATA AND PROCEDURES}

The basic data that we employ come from the 1982 Social Security New Beneficiary Survey (NBS). The NBS is a 1982 survey of individuals who received their first Social Security payment between June 1980 and June 1981 (Ycas, 1992). Our sample is composed of the female SSDI beneficiaries who were aged 20-65 when first interviewed in 1982. Surviving respondents and surviving spouses were resurveyed in 1991. In 1991, 74.8 percent of the 1982 disabled female respondents were still alive, and 89 percent of them were reinterviewed.

We make intertemporal comparisons of our primary sample with two comparison groups: male SSDI new beneficiaries and nondisabled females. The male comparison group comes from the NBS; we use it to address the question of how well disabled women fare compared to men who became new SSDI beneficiaries in the same period and were required to meet the same eligibility rules. The nondisabled female comparison group is based on observations from the Michigan Panel Study of Income Dynamics (PSID); a sample of nondisabled women are selected who, as of 1980, had a sufficient work history to be eligible for Social Security coverage and who were also aged 20-65 in 1982. We "matched" the samples of disabled and nondisabled women by classifying the two female groups by race, age, education, and marital status and creating cell weights which, when applied to the 1982 PSID nondisabled sample, distributes them among cells exactly as the disabled sample was distributed in $1982 .^{2}$ In these demographic dimensions, then, the two groups of women are forced by our cell matching weights to be

\footnotetext{
${ }^{2}$ The PSID nondisabled sample was drawn from the 1980 wave, because it was in that year that the NBS sample was first identified as sufficiently disabled to be eligible for SSDI benefits. We used responses regarding health status and the presence of disabling conditions to identify nondisabled women. In addition, we imposed a work history requirement that mimicked that of SSDI eligibility rules in order to ensure that the comparison group would have been eligible for SSDI benefits had they been disabled. Appendix I describes the selection and matching process in more detail.
} 
comparably distributed. ${ }^{3}$ Table 1 presents the number of disabled women in our NBS sample by year and the number in each of the two comparison samples.

\section{FEMALE RECIPIENTS OF DISABILITY INCOME TRANSFERS: A PROFILE}

Table 2 presents descriptive statistics for our weighted sample of disabled women in 1982, shortly after they first received SSDI benefits, and for the 1991 survivors of this group. At the time that they first received benefits, the average age of the women was 52 years, and they averaged fewer than 11 years of schooling. Over one-fifth of them were nonwhite. Compared to the 68 percent of all U.S. women aged 25-64 and the 53 percent of women aged 65-74 who were married, fewer than half of this disabled group were married. They were not a well-to-do group, with family income (in 1994 dollars) averaging less than $\$ 19,000$; the average ratio of their family income to the poverty line was about 2.0 and, in a year when 14 percent of all households were poor, one quarter of the families of these women were in poverty. $^{4}$

Although all of these disabled women were SSDI recipients in 1980-81, they could have returned to work (with consequent reductions or loss of SSDI benefits) by either the 1982 interview or the 1991 reinterview. ${ }^{5}$ The long-term earnings consequences of the disabling conditions of these women are reflected in the fact that only one-quarter of the families of these disabled women reported any earnings by either the spouse or disabled woman herself. Annual earned income (either the disabled

\footnotetext{
${ }^{3}$ Because our "matching" procedure redistributes the nondisabled sample, the PSID results cannot be interpreted as reflecting a nondisabled female population, but only a nondisabled sample whose characteristics are constrained to be identical as of 1982 to our sample of disabled women.

${ }^{4}$ Family income includes income only of the respondent, spouse, and children less than 18 years of age living in the family. In 1992 the NBS did not ask the income of other family or household members (see Appendix II).

${ }^{5}$ Other studies have documented the small percentage of the NBS disabled sample who return to work after first benefit receipt, and the especially low rate among disabled women (Hennessey and Dykacz, 1989, 1993; Hennessey and Muller, 1994; Muller, 1992).
} 
TABLE 1

Number of Observations,

Disabled Women and Men and Matched SSDI-Eligible Nondisabled Women, 1982 and 1991

\begin{tabular}{lcc}
\hline & & \\
& 1982 & 1991 \\
\hline Disabled women & 1,578 & 1,048 \\
Matched SSDI-eligible nondisabled women & 2,849 & 2,340 \\
Disabled men & 3,589 & 2,100 \\
\hline
\end{tabular}

Source: Disabled: NBS; nondisabled: PSID. 
TABLE 2

Newly Entitled Female Recipients of Social Security Disability Insurance Benefits: 1982, 1991

\begin{tabular}{|c|c|c|c|}
\hline & 1982 & 1991 & $\begin{array}{c}\text { \% Change } \\
82-91 \\
\end{array}$ \\
\hline \multicolumn{4}{|l|}{ Demographic Characteristics } \\
\hline Mean age (years) & 52.4 & 60.0 & $14.5 \%$ \\
\hline Mean education (years) & 10.7 & 10.7 & $0.0 \%$ \\
\hline Percentage nonwhite & $21.4 \%$ & $21.8 \%$ & $1.9 \%$ \\
\hline Percentage married & $48.6 \%$ & $39.7 \%$ & $-18.3 \%$ \\
\hline Mean family size & 1.9 & 1.6 & $-12.2 \%$ \\
\hline Percentage in South & $35.5 \%$ & n.a. & \\
\hline Percentage in West & $15.6 \%$ & n.a. & \\
\hline Percentage in Northeast & $21.2 \%$ & n.a. & \\
\hline \multicolumn{4}{|l|}{ Family Income Characteristics } \\
\hline Mean total family income & $\$ 18,567$ & $\$ 15,839$ & $-14.7 \%$ \\
\hline Mean income-to-needs ratio & 2.01 & 1.83 & $-9.0 \%$ \\
\hline Percentage poor & $25.0 \%$ & $25.0 \%$ & $0.0 \%$ \\
\hline \multicolumn{4}{|l|}{ Percentage of families with } \\
\hline transfer/pension income & $97.0 \%$ & $94.5 \%$ & $-2.6 \%$ \\
\hline Percentage of families with earnings & $29.5 \%$ & $20.4 \%$ & $-30.8 \%$ \\
\hline \multicolumn{4}{|l|}{ Percentage of disabled individuals } \\
\hline with earnings & $5.3 \%$ & $8.3 \%$ & $56.6 \%$ \\
\hline Percentage of women with spouse earnings & $25.5 \%$ & $14.3 \%$ & $-43.9 \%$ \\
\hline Percentage of families with asset income & $48.3 \%$ & $50.8 \%$ & $5.2 \%$ \\
\hline \multicolumn{4}{|l|}{ Mean family transfers plus } \\
\hline pension income & $\$ 10,565$ & $\$ 10,627$ & $0.6 \%$ \\
\hline Mean family earnings & $\$ 5,987$ & $\$ 3,858$ & $-35.6 \%$ \\
\hline Mean personal income & $\$ 8,827$ & $\$ 8,771$ & $-0.6 \%$ \\
\hline Mean spouse income & $\$ 8,472$ & $\$ 5,955$ & $-29.7 \%$ \\
\hline Mean asset income & $\$ 1,524$ & $\$ 1,138$ & $-25.3 \%$ \\
\hline
\end{tabular}

Note: Table includes full, weighted sample in 1982 and survivors in 1991. Figures in 1994 dollars. 
woman's own and/or that of her husband, if married) was less than $\$ 6000$ on average and accounted for only about one-third of the aggregate income of these families. Transfers (including SSDI) and pensions were received by virtually all families (97 and 95 percent in 1982 and 1991, respectively) and was the major source of income for the families of these women, accounting for about 57 percent of the aggregate income of this group or about $\$ 10,600$ on average. Finally, while about one-half of the families of these women received income from assets, the average amount was small, accounting for less than 10 percent of total income.

Over the subsequent decade, the average family income of these disabled women declined by almost 15 percent, in part because of the loss of husbands' income upon widowhood (spousal income contributions declined by about $\$ 2500$ ) and because of selective attrition among the women themselves. ${ }^{6}$ However, as a result of the decline in average family size, their family income-to-needs ratio fell by only about 9 percent. Over the 1982-1991 period, their own personal income remained virtually constant. Across all observations, transfer and pension income also remained constant, whereas income from assets declined on average by about $\$ 400$.

In sum, then, in 1982 these working-age disabled women represent a relatively poor segment of U.S. society; one quarter of them had income below the nation's poverty line after the receipt of SSDI benefits. On average, the disabled women contributed (from all income sources) about 48 percent of aggregate income of these families. Low marriage rates (only half of disabled women were married) and low labor force participation of husbands (only about half of these husbands record any earnings) contribute to the relatively low level of economic well-being of these women in 1982.

${ }^{6}$ The NBS sample of disabled women declined by 33 percent from 1982 to 1991, largely because of attrition due to death. Because the women who survived to 1991 had a somewhat lower income-to-needs ratio than all women in 1982 (1.99 compared to 2.01), selective attrition appears to have accounted for some of this decline in average income. Similarly, survivors until 1991 were somewhat less likely to have been married in 1982 (47 percent) than were all disabled women (48.6 percent). 
Over the subsequent decade, the husbands of some of those who were married as of 1982 left the family unit (largely through death). The transfer income (85 percent of which is SSDI benefits) received by the women remained constant over the period, and provided a base of income support over time. The decline in their average family size was insufficient to offset declining family income, and as a result the average ratio of income-to-needs declined by about 9 percent. However, in 1991, as in 1982, about onequarter of the disabled women (survivors, in this case) were poor. ${ }^{7}$

\section{HOW DO DISABLED WOMEN FARE RELATIVE TO THEIR NONDISABLED COUNTERPARTS?}

Understanding how this cohort of disabled women fared over time in face of their inability to work, as well as the role of SSDI in maintaining their relative economic well-being, requires comparison with a group who are similar in demographic characteristics but for their disabled status. Table 3 shows a variety of differences between the families of the disabled women and the comparison group of nondisabled women. ${ }^{8}$ Changes over the $1982-1991$ period in a variety of income measures for both the disabled women and the counterpart group of nondisabled women are shown. Because our primary interest is in how well disabled women fare over time, in this and subsequent tables the reported data for

${ }^{7}$ The poverty rate among all disabled women masks differences across women by marital status. Only 8 percent of disabled women who remained married were poor in 1991, compared to 33 percent of women who were widowed in both years and 41 percent of women who were divorced in both years. Almost 20 percent of the disabled women who became widows over the decade were poor in 1991, while 42 percent of those who became divorced were poor in 1991. Later in this paper we examine the influence of marital status and of marital status changes between 1982 and 1991 on the probability of being poor.

${ }^{8}$ Recall that as of 1980 , the year the NBS sample applied for SSDI benefits, these women had reported sufficient work experience and earnings to make them eligible for SSDI benefits had they become disabled. 
TABLE 3

Disabled and Matched SSDI-Eligible Nondisabled Women:

Changes in Economic Status, 1982 to 1991

\begin{tabular}{|c|c|c|c|}
\hline & 1982 & 1991 & $\begin{array}{c}\% \text { Change } \\
82-91\end{array}$ \\
\hline \multicolumn{4}{|l|}{ Family Income } \\
\hline Disabled & $\$ 18,436$ & $\$ 15,839$ & $-14 \%$ \\
\hline SSDI-eligible nondisabled & $\$ 30,875$ & $\$ 27,186$ & $-12 \%$ \\
\hline Disabled as $\%$ of nondisabled & $60 \%$ & $58 \%$ & $-2 \%$ \\
\hline \multicolumn{4}{|l|}{ Income-to-Needs Ratio } \\
\hline Disabled & 1.99 & 1.83 & $-8 \%$ \\
\hline SSDI-eligible nondisabled & 3.39 & 3.13 & $-8 \%$ \\
\hline Disabled as $\%$ of nondisabled & $59 \%$ & $58 \%$ & $-0 \%$ \\
\hline \multicolumn{4}{|l|}{ Percentage in Poverty } \\
\hline Disabled & $25 \%$ & $25 \%$ & $0 \%$ \\
\hline SSDI-eligible nondisabled & $11 \%$ & $18 \%$ & $64 \%$ \\
\hline Disabled as $\%$ of nondisabled & $227 \%$ & $139 \%$ & $-39 \%$ \\
\hline \multicolumn{4}{|l|}{ Percentage Near Poverty } \\
\hline Disabled & $23 \%$ & $26 \%$ & $13 \%$ \\
\hline SSDI-eligible nondisabled & $12 \%$ & $15 \%$ & $25 \%$ \\
\hline Disabled as $\%$ of nondisabled & $192 \%$ & $173 \%$ & $-10 \%$ \\
\hline \multicolumn{4}{|c|}{ Social Security as Percentage of Family Income } \\
\hline Disabled & $60 \%$ & $69 \%$ & $15 \%$ \\
\hline SSDI-eligible nondisabled & $16 \%$ & $42 \%$ & $162 \%$ \\
\hline Disabled as $\%$ of nondisabled & $375 \%$ & $164 \%$ & $-56 \%$ \\
\hline \multicolumn{4}{|c|}{ Transfers as Percentage of Family Income } \\
\hline Disabled & $65 \%$ & $72 \%$ & $11 \%$ \\
\hline SSDI-eligible nondisabled & $21 \%$ & $45 \%$ & $114 \%$ \\
\hline Disabled as $\%$ of nondisabled & $310 \%$ & $160 \%$ & $-48 \%$ \\
\hline \multicolumn{4}{|c|}{ Earnings as Percentage of Family Income } \\
\hline Disabled & $19 \%$ & $13 \%$ & $-32 \%$ \\
\hline SSDI-Eligible nondisabled & $61 \%$ & $31 \%$ & $-49 \%$ \\
\hline Disabled as $\%$ of nondisabled & $31 \%$ & $42 \%$ & $35 \%$ \\
\hline \multicolumn{4}{|c|}{ Husbands' Income as \% of Total-All Women } \\
\hline Disabled & $32 \%$ & $27 \%$ & $-16 \%$ \\
\hline SSDI-eligible nondisabled & $31 \%$ & $27 \%$ & $-13 \%$ \\
\hline Disabled as $\%$ of nondisabled & $\begin{array}{c}103 \% \\
\text { table conti }\end{array}$ & $100 \%$ & $-3 \%$ \\
\hline
\end{tabular}


TABLE 3, continued

\begin{tabular}{lccc}
\hline & & & $\%$ Change \\
& 1982 & 1991 & $82-91$ \\
\hline & & & \\
Husbands' Income as \% of Total-Married Couples Only & & $-3 \%$ \\
$\quad$ Disabled & $67 \%$ & $65 \%$ & $5 \%$ \\
SSDI-eligible nondisabled & $59 \%$ & $62 \%$ & $-8 \%$ \\
Disabled as \% of nondisabled & $114 \%$ & $105 \%$ & \\
& & & $-15 \%$ \\
Percent Married* & $47 \%$ & $40 \%$ & $-14 \%$ \\
Disabled & $49 \%$ & $42 \%$ & \\
SSDI-eligible nondisabled & $96 \%$ & $95 \%$ & $-11 \%$ \\
Disabled as \% of nondisabled & & & $-17 \%$ \\
& & & \\
Family Size & 1.9 & 1.7 & \\
Disabled & 2.3 & $89 \%$ & \\
SSDI-eligible nondisabled & $83 \%$ & & \\
Disabled as \% of nondisabled & & & \\
\hline
\end{tabular}

Notes: 1982 data are only for women still in the sample in 1991. Figures in 1994 dollars. Near poverty is between 1.0 and 1.5 of poverty threshold. Nondisabled sample is weighted by both sample and matching weights.

*This variable is a characteristic upon which the "matching" was based. 
1982 are only for women who survive to $1991 .^{9}$ The impact of a disabling condition on the economic well-being of the families of these women is substantial. For both 1982 and 1991, the level of household income and the income-to-needs ratio of the disabled women are equal to about 60 percent of those of their nondisabled counterparts. In 1982, 48 percent of disabled women lived in families who were poor or near poor (whose ratio of income to the family-specific poverty line is 1.5 or less), and this increased to 51 percent over the ten-year period. The comparable percentage for the nondisabled women was 23 percent in 1982 (less than one-half that of the disabled women), rising to 33 percent in 1991.

As would be expected in comparing SSDI recipients with a nondisabled group of women, the role of income transfers (and in particular, Social Security-including SSDI) in family income is substantially different. While Social Security income is the major source of family income for the disabled women in 1982, accounting for 60 percent of income (about $\$ 11,000$ on average), earned income is the largest component of the income of the nondisabled, accounting for over 60 percent of these families' income (about $\$ 17,000$ on average). By 1991, when 47 percent of the disabled sample had reached 65 , Social Security income accounts for nearly 70 percent of the family income of the disabled, but for only 42 percent of the family income of the age-matched nondisabled sample.

The steady contribution of Social Security income to well-being is one explanation for poverty rates not increasing over time among women with disabilities. For the nondisabled women, Social Security income increased as a share of family income as they or their husbands retired, but this increase failed to fully offset the reduction in earnings, resulting in an increase in their poverty rate from 11 percent to 18 percent. Nevertheless, the average disabled-nondisabled income gap remained nearly

${ }^{9}$ For this reason 1982 figures for disabled women in Table 3 may be somewhat different from the 1982 percentages in Table 2, which are for the full 1982 sample, including those who attrited before 1991. Because the PSID matching cell weights were developed by comparing the full 1982 samples of disabled and nondisabled observations, small differences in "matching" characteristics in 1982 between the NBS and PSID observations who survived exist. Overall patterns of change are the same for the entire 1982 sample and the surviving 1991 women. 
constant over the period; as noted above, by 1991 the percentage of the disabled women living in poor or near-poor families was 51 percent, compared with 33 percent for the nondisabled women.

In 1982 husbands contributed about one-third of the aggregate income of the families of both the disabled and matched nondisabled women. Looking only at married women, the husbands of the disabled women contributed two-thirds of the income of the family, while husbands of women without disabilities contributed just under 60 percent. ${ }^{10}$ Over the subsequent decade, the share of family income contributed by husbands declined for the disabled women, but increased for nondisabled women; by 1991 husbands of disabled and of nondisabled women contributed almost identical shares to family income.

In sum, disabled women live at a substantially lower level of economic well-being than do their nondisabled counterparts. Indeed, for disabled women who are married, husband's income does not compensate for the wife's lower earnings. Even though the husbands of disabled women contribute a higher share of the total income of these families, their absolute contribution is lower than that of husbands of nondisabled women. Transfer, and especially Social Security, income plays a crucial role in sustaining even the modest, and often below-poverty level, incomes of disabled women. Over time as disabled and nondisabled women entered retirement ages, the absolute level of Social Security income and its share of total family income increased. However, these increases did not prevent a decline in overall income and economic well-being.

\section{HOW DO DISABLED WOMEN FARE RELATIVE TO DISABLED MEN?}

Our comparison of incomes of disabled with (matched) nondisabled females over time has revealed absolute and relative economic hardship for the former group which persisted over the decade following their first receipt of disability-related income support. The lower average family income of

\footnotetext{
${ }^{10}$ The average personal income of the husbands of disabled women was $\$ 12,352$, compared to an income of $\$ 16,525$ for the husbands of nondisabled women.
} 
disabled women is largely due to their work-limiting disabilities, the limited replacement of lost earnings by SSDI, and the lower earnings of their spouses. However, even though the families of these women may fare worse than those of nondisabled women, it may be that their economic situation is no worse, or even better, than that of men who entered the program at the same time. The latter would be the case, for example, if disability for a woman who is married to a nondisabled man is less economically devastating than it is for a family in which the male primary wage earner becomes disabled. Thus, a comparison of the economic position of disabled women relative to their disabled male counterparts interviewed in the NBS is of considerable interest. Table 4 presents comparative information on these two groups, analogous to that in Table 3.

Among both disabled men and women, the effect of a disabling condition on economic wellbeing is evident, although the families of the disabled men live at a somewhat higher level relative to the nation's poverty line than do those of the disabled women. Over the period, real total family income of disabled men fell by 7 percent, compared to a decrease of 14 percent for disabled women. However, because the average family size of the men declined over the period from 2.4 to 2.0 , their consumption needs fell faster than their family income. ${ }^{11}$ As a result, the income-to-needs ratio of disabled men remained at about 2.1, compared to the fall in the ratio from 2 to about 1.8 among disabled women. Although disabled women began the period with an income-to-needs ratio equal to about 93 percent of that of disabled men, the ratio fell to 86 percent some 9 years later. For disabled women, the proportion

\footnotetext{
${ }^{11}$ The greater decline in the average family size of disabled men than of disabled women may be surprising, given higher mortality rates for men and the more rapid decline in the percentage of disabled women who are married. The explanation is that disabled men began with more dependent children, a consequence of these men's wives being on average younger than the disabled women, and the departure of these children as they age. Among disabled men, the number of dependent children is .32 fewer in 1991 than 1982; among disabled women the reduction is .18. Over this period, the average decline in the number of adults across all households is about .06 for both disabled men and women. It must also be noted that it is the survivors in 1991 who are being compared; this requirement modifies the impact of differential mortality that might otherwise have been observed.
} 
TABLE 4

Disabled Women and Disabled Men: Changes in Economic Status, 1982 to 1991

\begin{tabular}{|c|c|c|c|}
\hline & 1982 & 1991 & $\begin{array}{c}\text { \% Change } \\
82-91\end{array}$ \\
\hline \multicolumn{4}{|l|}{ Family Income } \\
\hline Disabled women & $\$ 18,436$ & $\$ 15,839$ & $-14 \%$ \\
\hline Disabled men & $\$ 21,846$ & $\$ 20,402$ & $-7 \%$ \\
\hline Disabled women as $\%$ of disabled men & $84 \%$ & $78 \%$ & $-8 \%$ \\
\hline \multicolumn{4}{|l|}{ Income-to-Needs Ratio } \\
\hline Disabled women & 1.99 & 1.83 & $-8 \%$ \\
\hline Disabled men & 2.13 & 2.13 & $0 \%$ \\
\hline Disabled women as $\%$ of disabled men & $93 \%$ & $86 \%$ & $-8 \%$ \\
\hline \multicolumn{4}{|l|}{ Percentage in Poverty } \\
\hline Disabled women & $25 \%$ & $25 \%$ & $0 \%$ \\
\hline Disabled men & $21 \%$ & $17 \%$ & $-19 \%$ \\
\hline Disabled women as $\%$ of disabled men & $119 \%$ & $147 \%$ & $24 \%$ \\
\hline \multicolumn{4}{|l|}{ Percentage Near Poverty } \\
\hline Disabled women & $23 \%$ & $26 \%$ & $13 \%$ \\
\hline Disabled men & $21 \%$ & $19 \%$ & $-10 \%$ \\
\hline Disabled women as \% of disabled men & $110 \%$ & $137 \%$ & $25 \%$ \\
\hline \multicolumn{4}{|l|}{ Social Security as Percentage of Family Income } \\
\hline Disabled women & $60 \%$ & $69 \%$ & $15 \%$ \\
\hline Disabled men & $58 \%$ & $63 \%$ & $9 \%$ \\
\hline Disabled women as $\%$ of disabled men & $103 \%$ & $110 \%$ & $6 \%$ \\
\hline \multicolumn{4}{|l|}{ Transfers as Percentage of Family Income } \\
\hline Disabled women & $65 \%$ & $72 \%$ & $11 \%$ \\
\hline Disabled men & $63 \%$ & $65 \%$ & $3 \%$ \\
\hline Disabled women as $\%$ of disabled men & $103 \%$ & $111 \%$ & $7 \%$ \\
\hline \multicolumn{4}{|l|}{ Earnings as Percentage of Family Income } \\
\hline Disabled women & $19 \%$ & $13 \%$ & $-32 \%$ \\
\hline Disabled men & $18 \%$ & $15 \%$ & $-17 \%$ \\
\hline Disabled women as \% of disabled men & $106 \%$ & $87 \%$ & $-18 \%$ \\
\hline \multicolumn{4}{|c|}{ Spouses' Income as \% of Total-All Individuals } \\
\hline Disabled women & $32 \%$ & $27 \%$ & $-16 \%$ \\
\hline Disabled men & $28 \%$ & $27 \%$ & $-4 \%$ \\
\hline Disabled women as $\%$ of disabled men & $114 \%$ & $100 \%$ & $-12 \%$ \\
\hline
\end{tabular}

(table continues) 
TABLE 4, continued

\begin{tabular}{lccc}
\hline & & & $\%$ Change \\
& 1982 & 1991 & $82-91$ \\
\hline & & & \\
Spouses' Income as \% of Total-Married Couples Only & & $-3 \%$ \\
$\quad$ Disabled women & $67 \%$ & $65 \%$ & $3 \%$ \\
$\quad$ Disabled men & $31 \%$ & $32 \%$ & $-6 \%$ \\
$\quad$ Disabled women as \% of disabled men & $216 \%$ & $203 \%$ & \\
& & & $-15 \%$ \\
Percentage Married* & & & $-14 \%$ \\
$\quad$ Disabled women & $47 \%$ & $40 \%$ & $-1 \%$ \\
$\quad$ Disabled men & $49 \%$ & $42 \%$ & \\
$\quad$ Disabled women as \% of disabled men & $96 \%$ & $95 \%$ & $-11 \%$ \\
& & & $-17 \%$ \\
Family Size & & 1.7 & $7 \%$ \\
$\quad$ Disabled women & 1.9 & 2.0 & \\
$\quad$ Disabled men & 2.4 & & \\
$\quad$ Disabled women as \% of disabled men & $79 \%$ & & \\
\hline
\end{tabular}

Notes: 1982 data are only for women still in the sample in 1991. Figures in 1994 dollars. Near poverty is between 1.0 and 1.5 of poverty threshold.

*This variable is a characteristic upon which the "matching" was based. 
who lived in families that were either poor or near poor increased from 48 to 51 percent over the period, while the proportion for disabled men began the period at 42 and then decreased to 36 percent.

Tables 3 and 4 show that the spouses of both male and female SSDI recipients account for between one-quarter and one-third of total family income. This is the result of two offsetting factors. First, disabled women are less likely to be married than are disabled men. Second, the husbands of disabled women contribute a substantially greater share of family income than do the wives of disabled men. Indeed, husbands, whether they are themselves disabled or are married to disabled women, contribute on average two-thirds of family income, while both married disabled women and women married to the disabled men account for one-third of family income.

Over the 1982-1991 period, income sources changed as the working spouses of both disabled groups retired and had earned income replaced by retired-worker benefits, and as spouses died.

Consistent with the retirement or death of some spouses (with the subsequent receipt of Social Security retired worker or survivor benefits), Social Security benefits played an important, and growing, role in sustaining economic status for both disabled groups, increasing from 60 to 69 percent of family income for women and from 58 to 63 percent of family income for men.

The picture here, then, is of two highly disadvantaged groups, but with disabled males faring somewhat better economically than the counterpart group of disabled females. The poverty plus nearpoverty rate was over 40 percent for both groups in 1982, but fell to 36 percent for disabled men while it rose to 51 percent for disabled women. This pattern is caused in part by the lower marriage rate of women. In addition, husbands of disabled women did not compensate by increasing their contribution to family income. At the beginning of the period, Social Security benefits were the major income source for both genders of disabled people; over time, the role of this form of public income support in sustaining economic status increased among both groups. 


\section{PREDICTORS OF NEAR-POOR STATUS AMONG DISABLED AND NONDISABLED WOMEN}

As we have seen, the difference in poverty levels between disabled and matched nondisabled women is substantial. Defining those with an income-to-needs ratio of less than 1.5 as "near poor," we found that 48 percent of disabled women fell below this threshold in 1982, as did 51 percent in 1991. The nondisabled women have substantially lower near-poor rates, 23 percent and 33 percent, in the two years. Differences in means of characteristics, however, do not convey the relative importance of factors underlying these disparities.

In Table 5 we examine the independent effect of various sociodemographic characteristics on the probability of being near poor in the given year (1982 or 1991). We estimate these effects using a bivariate probit model in order to take account of the unobserved factors that are likely to be correlated with a household's poverty status in both years. ${ }^{12}$ Below each coefficient and its standard error we show the marginal effect of each factor on the chances of being below the near-poor threshold. The marginal effects are evaluated at the mean of all variables and show the effect of a marginal change in continuous variables and a change from zero to one in the dichotomous variables.

For disabled women in 1982, being unmarried, having children (under 18) living in the family, being nonwhite, having low levels of schooling (more than high school is the excluded category), and living in the South are positively and significantly associated with being poor or near poor. While being young when first coming on the disability rolls (age less than 35 years in 1982) increases the probability of being below the near-poor threshold (compared to the risk among the excluded age 52-54 group), no

\footnotetext{
${ }^{12}$ In the presence of unobserved factors, knowledge of poverty status in 1982 conveys information about poverty status in 1991. A bivariate probit model allows for correlation in the error terms of the two probit estimates, reflecting this likely persistence of unmeasured characteristics within the group over time. The large positive and significant "rho" value in both estimates indicates the strong persistence of these characteristics over time.
} 
TABLE 5

Bivariate Probit of Being below the Near-Poor Threshold, Disabled and Matched Nondisabled Women

(Coefficient, Standard Error, and Marginal or Discrete Effect)

\begin{tabular}{|c|c|c|c|c|}
\hline \multirow[b]{2}{*}{ Variable } & \multicolumn{2}{|c|}{ Disabled } & \multicolumn{2}{|c|}{ Nondisabled } \\
\hline & 1982 & 1991 & 1982 & 1991 \\
\hline Constant & $\begin{array}{r}-0.123 \\
0.203 \\
-0.149\end{array}$ & $\begin{array}{c}-0.972 * \\
0.218 \\
-1.175\end{array}$ & $\begin{array}{c}-2.128^{*} \\
0.203 \\
-1.422\end{array}$ & $\begin{array}{c}-1.761^{*} \\
0.225 \\
-1.176\end{array}$ \\
\hline $\begin{array}{c}\text { Age in } 1982 \\
\text { Age }<35\end{array}$ & $\begin{array}{l}0.521 * \\
0.199 \\
0.097\end{array}$ & $\begin{array}{l}0.597 * \\
0.193 \\
0.088\end{array}$ & $\begin{array}{l}0.543 \\
0.161 \\
0.031\end{array}$ & $\begin{array}{l}0.239 \\
0.191 \\
0.015\end{array}$ \\
\hline Age $35-51$ & $\begin{array}{l}0.306 \\
0.168 \\
0.062\end{array}$ & $\begin{array}{l}0.167 \\
0.163 \\
0.030\end{array}$ & $\begin{array}{l}0.265^{*} \\
0.141 \\
0.015\end{array}$ & $\begin{array}{l}0.208 \\
0.154 \\
0.013\end{array}$ \\
\hline Age $55-58$ & $\begin{array}{l}0.092 \\
0.176 \\
0.019\end{array}$ & $\begin{array}{r}-0.092 \\
0.166 \\
-0.017\end{array}$ & $\begin{array}{l}0.639 * \\
0.140 \\
0.037\end{array}$ & $\begin{array}{l}0.418^{*} \\
0.154 \\
0.027\end{array}$ \\
\hline Age 59-61 & $\begin{array}{l}0.031 \\
0.170 \\
0.007\end{array}$ & $\begin{array}{r}-0.116 \\
0.167 \\
-0.022\end{array}$ & $\begin{array}{l}0.383^{*} \\
0.148 \\
0.022\end{array}$ & $\begin{array}{l}0.584^{*} \\
0.154 \\
0.038\end{array}$ \\
\hline Age $62-65$ & $\begin{array}{l}0.065 \\
0.177 \\
0.014\end{array}$ & $\begin{array}{r}-0.067 \\
0.178 \\
-0.012\end{array}$ & $\begin{array}{l}0.689 * \\
0.142 \\
0.040\end{array}$ & $\begin{array}{l}0.341 \\
0.162 \\
0.022\end{array}$ \\
\hline Married & $\begin{array}{c}-1.256^{*} \\
0.093 \\
-0.255\end{array}$ & - & $\begin{array}{c}-0.258 * \\
0.073 \\
-0.014\end{array}$ & - \\
\hline $\begin{array}{c}\text { Single in 1982/ } \\
\text { single in } 1991\end{array}$ & - & $\begin{array}{l}1.120^{*} \\
0.098 \\
0.194\end{array}$ & - & $\begin{array}{l}0.290^{*} \\
0.083 \\
0.018\end{array}$ \\
\hline $\begin{array}{l}\text { Single in 1982/ } \\
\text { married in } 1991\end{array}$ & - & $\begin{array}{r}-0.015 \\
0.221 \\
-0.003\end{array}$ & - & $\begin{array}{r}-0.100 \\
0.186 \\
-0.006\end{array}$ \\
\hline $\begin{array}{l}\text { Married in } 1982 / \\
\text { single in } 1991\end{array}$ & - & $\begin{array}{l}0.691 * \\
0.135 \\
0.098\end{array}$ & - & $\begin{array}{l}0.282^{*} \\
0.108 \\
0.018\end{array}$ \\
\hline
\end{tabular}

(table continues) 
TABLE 5, continued

\begin{tabular}{|c|c|c|c|c|}
\hline \multirow[b]{2}{*}{ Variable } & \multicolumn{2}{|c|}{ Disabled } & \multicolumn{2}{|c|}{ Nondisabled } \\
\hline & 1982 & 1991 & 1982 & 1991 \\
\hline \multirow{3}{*}{$\begin{array}{l}\text { Number of children } \\
\text { at home }\end{array}$} & $0.328 *$ & 0.093 & $0.295^{*}$ & 0.039 \\
\hline & 0.066 & 0.058 & 0.047 & 0.047 \\
\hline & 0.396 & 0.112 & 0.197 & 0.026 \\
\hline \multirow[t]{3}{*}{ White } & $-0.357 *$ & $-0.396 *$ & $-0.406^{*}$ & $-0.274 *$ \\
\hline & 0.116 & 0.119 & 0.079 & 0.085 \\
\hline & -0.072 & -0.066 & -0.023 & -0.017 \\
\hline \multirow[t]{3}{*}{ Less than HS education } & $0.885^{*}$ & $1.0068^{*}$ & $1.35^{*}$ & $0.642 *$ \\
\hline & 0.144 & 0.142 & 0.148 & 0.136 \\
\hline & 0.159 & 0.144 & 0.073 & 0.042 \\
\hline \multirow[t]{3}{*}{ Some HS education } & $0.544^{*}$ & $0.589^{*}$ & $1.315^{*}$ & $0.682 *$ \\
\hline & 0.137 & 0.134 & 0.146 & 0.136 \\
\hline & 0.106 & 0.094 & 0.072 & 0.044 \\
\hline \multirow[t]{3}{*}{ HS graduate } & $0.442 *$ & $0.305^{*}$ & $0.733 *$ & $0.342 *$ \\
\hline & 0.131 & 0.122 & 0.140 & 0.126 \\
\hline & 0.089 & 0.053 & 0.041 & 0.022 \\
\hline \multirow[t]{3}{*}{ South } & $0.382 *$ & $0.321 *$ & $0.584 *$ & $0.332 *$ \\
\hline & 0.109 & 0.108 & 0.089 & 0.086 \\
\hline & 0.080 & 0.057 & 0.033 & 0.021 \\
\hline \multirow[t]{3}{*}{ Northeast } & -0.034 & -0.083 & -0.115 & $-0.598 *$ \\
\hline & 0.133 & 0.131 & 0.122 & 0.138 \\
\hline & -0.007 & -0.015 & -0.006 & -0.032 \\
\hline \multirow[t]{3}{*}{ West } & 0.032 & -0.119 & -0.150 & $-0.400 *$ \\
\hline & 0.152 & 0.146 & 0.136 & 0.138 \\
\hline & 0.007 & -0.002 & -0.008 & -0.022 \\
\hline \multirow[t]{2}{*}{ Rho } & & $0.700 *$ & & $0.406^{*}$ \\
\hline & & 0.037 & & 0.044 \\
\hline Mean dependent & 0.477 & 0.508 & 0.228 & 0.333 \\
\hline Log likelihood & & -1031 & & -1813 \\
\hline $\mathrm{N}$ & & 1048 & & 2340 \\
\hline Sum of weights & & 1048 & & 1513 \\
\hline
\end{tabular}

Notes Near-poor threshold is 1.5 times poverty threshold; nondisabled sample is weighted with matching weights. Marginal effect is the effect of a marginal change in the regressor on the probability of being poor in the given period. Discrete effect, reported for dichotomous regressors, is the effect of a change in the regressor from zero to one on the probability of being poor in the given period. See text for details. *Statistically significantly different from zero at the $5 \%$ level. 
other age at disability onset changes the probability of being near poor. ${ }^{13}$ Young disabled women appear to be disadvantaged both because they enter recipiency with a shorter work history and because their SSDI benefits are based exclusively on work during the traditionally lower earnings years. ${ }^{14}$ This age pattern suggests that either the Social Security benefit formula or the long-term effects of disabling conditions moderate the hump-shaped, age-related poverty profile seen among nondisabled women. ${ }^{15}$

The pattern of probit coefficients for nondisabled women in 1982 is quite similar to that of disabled women except for the age coefficients and the magnitude of many of the marital status change coefficients. As with the disabled women, not being married, having minor children living at home, being nonwhite, and having low education add independent, positive, and significant effects to the probability of being poor or near poor. Compared to women who in 1982 were 52-54, the ages when real family earnings are likely to peak, both younger and older nondisabled women face a higher risk of being below the near-poor threshold. This is consistent with older women (and their husbands) reducing their earnings because of retirement and younger women (and their husbands) being on a rising earnings trajectory.

In 1991, the effects of education, race, and children persist for both groups, although the effect of children diminishes as fewer children remain at home, reducing family needs, and as older children may contribute to family income. As the youngest group of disabled women age over the decade, their higher relative risk of poverty is attenuated somewhat, perhaps because some marry and others are able to supplement SSDI income with modest earnings. Among the nondisabled, retirement effects appear to

\footnotetext{
${ }^{13}$ The age groupings are identical to those used in the matching procedure (Appendix I). In both cases they were chosen in order to group individuals in similar parts of the life cycle and to differentiate groups who would enter the peak earning years or attain the early or normal age of eligibility for Social Security retired-worker benefits.

${ }^{14}$ The fully insured and recent covered work requirements for SSDI mean that persons entering the SSDI rolls at older ages will have had more earning years and, in calculating SSDI benefits, will be more likely to eliminate some early years with low or zero earnings from the benefit formula. By 1991 this effect of being in the youngest age group is diminished, but has the same sign and is significant at the .01 level.

${ }^{15}$ Interestingly, disabled women entering the SSDI rolls at 62-65, the age of early retirement, appear to have the same risk of being near poor as do women who become disability recipients at a much earlier age.
} 
dominate near-poverty differences. Compared to the excluded age group (age 52-54 in 1982 and 61-63 in 1991) the three older age categories (spanning 64-74 in 1991) face a higher risk of being below the near-poverty threshold. Not surprisingly, the relative risk of being poor or near poor for the youngest age group diminishes over this time period as the economic well-being of the excluded group becomes increasingly tied to retirement income and the youngest group has entered the peak earnings years.

We also measure the effect of changes in marital status over the 1982 to 1991 period on the probability of being poor or near poor in the latter year. Consider first the effects for disabled women. Compared to women who are married in both years (the excluded group), moving from being married to being single has a positive and significant effect on the probability of being poor or near poor in 1991, while moving from being single to being married appears to have little if any effect on this relative risk in the second year. ${ }^{16}$ Remaining single is associated with an even higher risk of being poor or near poor in 1991 than is becoming single; the risk of being poor or near poor is higher by 19.4 percentage points compared to the risk faced by those who remain married.

The effect of marital status changes on poverty in 1991 for nondisabled women is also significant, but the marginal effect is far smaller. For example, although remaining single over the period has a negative impact on economic status, because the lower consumption needs of these families do not compensate for absence of spousal contributions to family income, the risk of being poor or near poor is less that 2 percentage points higher than the risk among those who remain married. As with the disabled women, moving from being married to being single has a significant and positive effect on being poor or near poor in the later year, but the marginal effect is only one-fifth as large. Indeed, except for being 55+ (after which the nondisabled reduce earnings because of retirement), conditions that increase the risk of

\footnotetext{
${ }^{16}$ Although unmarried women are far more likely to be near poor than are married women in 1982, when they marry, their risk of being near poor in 1991 is not different from that of women married in both years.
} 
poverty or near poverty do so to a far larger degree among the disabled women than among their nondisabled counterparts.

Overall, then, these estimates suggest that those factors that are negatively related to labor market earnings—young age, low education, nonwhite, unmarried (either remaining single or moving from married to unmarried), and living in the South—tend to have a stronger independent effect on the probability of being below the near-poverty threshold for disabled than for nondisabled women. In effect, while the income support provided by Social Security and the other transfers available to disabled women weakens the independent effect of these labor market factors in determining the probability of being poor, these transfers do not entirely mitigate the larger effect of risk factors for the disabled. Consequently, while the pattern of these independent effects may be similar for the two groups, their marginal effect on the disabled is substantially larger and contributes to the substantially higher overall poverty rates of disabled women relative to women without disabilities.

\section{THE ANTIPOVERTY EFFECTIVENESS OF SOCIAL SECURITY BENEFITS}

Our results have emphasized the substantial role of Social Security benefits in supporting the economic well-being of disabled persons. Nevertheless, poverty remains high for the disabled group. In this section we explore in more detail how the Social Security program (primarily SSDI) contributes to the well-being of the disabled. We explore this issue in three ways. First we examine the effect of Social Security income support in removing from poverty disabled women and disabled men. ${ }^{17}$ Second, we calculate the "poverty gap" (the difference between pre-Social Security income and the poverty threshold) and examine the success of Social Security transfers in filling this gap (Danziger and Weinberg, 1994). Our final approach is to estimate potential "without-disability" earnings for disabled

\footnotetext{
${ }^{17} \mathrm{We}$ use the narrower definition of poverty here; those who live in families whose income is below the poverty line.
} 
women and men, and then to measure the extent to which Social Security transfers replace those earnings in 1982 and 1991. These three approaches provide information, respectively, on the relative success of SSDI in moving families of disabled women and men above the poverty threshold, the relative size of the poverty gap that remains to be filled after Social Security benefits are paid, and the extent to which the SSDI formula, which bases benefits on average earnings, replaces earnings lost because of a disabling condition. ${ }^{18}$

In estimating the antipoverty impact of Social Security benefits, we first calculate the level of family income for each disabled woman and man, excluding from reported income any benefits from Social Security and Supplemental Security Income (SSI) paid to either the disabled woman or her spouse, if married. We compare this income value to the family-specific poverty line and label the resulting poverty incidence "pre-Social Security poverty." Absent any behavioral adjustment, this comparison reveals whether or not the person would have been in a poor family with all income sources except Social Security and SSI income counted. Because some persons would be eligible for SSI disability payments were there no Social Security program, we next calculate the SSI benefits for which the woman (and her husband, if married) would have been eligible based on assets and reported income other than Social Security. This enables us to estimate whether or not the family of the woman would have been poor if her potential SSI income were included in the income total. From these individual calculations, we calculate the "pre-Social Security poverty rate with simulated SSI." Comparing the actual post-Social Security poverty rate for each group with these simulated poverty rates enables a calculation of the proportion of the pre-Social-Security-poor individuals that are raised above the poverty line solely by receipt of Social

\footnotetext{
${ }^{18}$ The SSI benefits are simulated (in contrast to using the reported SSI benefits) in order to take into account the full potential benefit from SSI for all persons who would be eligible for this program in the absence of SSDI. The benefit amount is determined by computing the insured beneficiary's average indexed monthly earnings and then applying a formula to derive the primary insurance amount (PIA). For workers under age 47 , there is a stricter limit on the number of years that can be excluded.
} 
Security benefits. ${ }^{19}$ We follow the same procedure for the families of disabled men. Table 6 presents these calculations for disabled women and men.

In 1982, at the time the disabled groups first received SSDI benefits, the pre-Social Security poverty rate would have been about 63 and 60 percent for disabled women and men, respectively. SSI alone would have moved fewer than 4 percent of these families out of poverty. In fact, actual poverty rates were less than one-half of this level-25 percent for women and 21 percent for men. For these disabled groups of 20- to 64-year-olds, Social Security benefits removed at least 60 percent of the preSocial Security poor from poverty-60 percent of the women were removed and 65 percent of the men. The greater antipoverty effectiveness of Social Security for men relative to women is due to the higher average benefit levels paid in the program to men (because of their higher earnings during the period used for benefit calculation), as well as to the higher proportion of disabled men who are married (and therefore with wives and younger children eligible for and perhaps receiving dependent benefits).

The final row of the panel shows the poverty gap (or the aggregate dollar difference between the poverty threshold for each family and pre-Social Security poverty plus actual SSI income) filled by Social Security payments. ${ }^{20}$ In 1982 , among the pre-Social Security poor in our sample of disabled persons, Social Security payments filled on average 81-82 percent of the poverty gap for both disabled men and women.

${ }^{19}$ This calculation ignores any behavioral responses that individuals or families might make if they had no SSDI income. One of the most likely of these neglected responses would entail additional work by either the person or one their family members. This problem is likely to be more serious for nondisabled males and females than for those with disabilities, as those who apply for SSDI benefits are unlikely to return to work.

${ }^{20}$ This gap is equal to zero if the pre-Social Security income of a family is above the poverty threshold. Actual SSI is used in this simulation in order to give us a measure of the actual size of the gap to be filled relative to actual Social Security payment. 
TABLE 6

\section{Antipoverty Effectiveness of Social Security Benefits and Simulated SSI Benefits among} Disabled Women and Men, 1982 and 1991

\begin{tabular}{lll}
\hline & Women & Men \\
\hline$\frac{1982}{\text { Pre-Social Security poverty rate }}$ & & \\
Pre-Social Security poverty with simulated SSI & $63 \%$ & $60 \%$ \\
Actual post-Social Security poverty & $61 \%$ & $56 \%$ \\
Simulated poor removed from poverty by SSI & $25 \%$ & $21 \%$ \\
Actual poor removed from poverty by Social Security & $60 \%$ & $7 \%$ \\
Aggregate poverty gap filled by Social Security & $3 \%$ & $65 \%$ \\
\hline Pre-Social Security poverty rate & $82 \%$ & $81 \%$ \\
Pre-Social Security poverty with simulated SSI & & $62 \%$ \\
Actual post-Social Security poverty & $72 \%$ & $59 \%$ \\
Simulated poor removed from poverty by SSI & $70 \%$ & $17 \%$ \\
Actual poor removed from poverty by Social Security & $65 \%$ & $5 \%$ \\
\hline Aggregate poverty gap filled by Social Security & $25 \%$ & $73 \%$ \\
\hline
\end{tabular}

Notes: Poverty is defined as receiving total income below the needs threshold. Aggregate poverty gap is needs threshold minus pre-Social Security family income, summed over all poor families. Poverty gap filled by Social Security is the aggregate Social Security benefit divided by the aggregate poverty gap. Poverty gap filled by Social Security is calculated for poor households only. 
Substantial increases in the antipoverty impact of Social Security benefits are observed from 1982 to 1991. In 1982, all but a few of these disabled individuals were out of the labor force, with SSDI benefits and spousal income, if married, providing the primary sources of income support. Between 1982 and 1991, the primary change that affected them was the loss of income due to the retirement or death of spouses. As a result of spousal income being replaced by the spouse's own Social Security benefits (or survivor benefits, if higher than disability benefits), pre-Social Security poverty rates rose for both disabled women and men (from 63 to 72 percent and from 60 to 62 percent, respectively). The receipt of Social Security benefits (both those paid to the disabled individual as well as to other family members) reduced their pre-Social Security poverty rate to 25 percent for women (unchanged from 1982) and to 17 percent for men (down from 21 percent in 1982). ${ }^{21}$

For both disabled men and disabled women, Social Security benefits increased their impact in moving people above the poverty line over the 1982 to 1991 period. By 1991, nearly two-thirds of the women who were pre-Social Security poor and about 73 percent of the men who were pre-Social Security poor are lifted above the poverty line by public social insurance income support. Social Security payments were also somewhat more effective in closing the poverty gap. By 1991, over 85 percent of the poverty gap was closed for the average pre-Social Security poor family headed by a SSDI recipient.

Our third measure of Social Security replacement effects is based on a comparison of what the disabled person receives from Social Security relative to an estimate of what that person could have earned had the individual not been disabled and receiving SSDI. Table 7 provides this estimated replacement rate, based upon the Social Security covered earnings records linked to the NBS data set.

\footnotetext{
${ }^{21}$ At age 65, SSDI beneficiaries are automatically converted to retired-workers status. This is an administrative conversion which does not in any way change the benefits for which they are eligible. The only effect is to make them subject to the retired-worker earnings limits rather than SSDI's substantial gainful work activity test.
} 
TABLE 7

SSDI Replacement Rates of Predisability Earnings

\begin{tabular}{|c|c|c|c|c|c|}
\hline & $\begin{array}{l}\text { Mean } \\
\text { Actual } \\
\text { Income }\end{array}$ & $\begin{array}{l}\text { Maximum } \\
\text { Predisability } \\
\text { Earnings }\end{array}$ & $\begin{array}{c}\text { Mean Predicted } \\
\text { Income Using } \\
\text { Average Predisability } \\
\text { Earnings } \\
\text { (Working Years) }\end{array}$ & $\begin{array}{l}\text { Mean Replac } \\
\text { Actual/Max. }\end{array}$ & 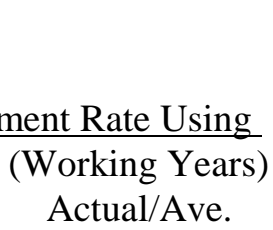 \\
\hline \multicolumn{6}{|l|}{1982} \\
\hline \multicolumn{6}{|c|}{ Above Poverty } \\
\hline Women & $\$ 27,609$ & $\$ 40,529$ & $\$ 31,073$ & $68 \%$ & $89 \%$ \\
\hline Men & $\$ 30,144$ & $\$ 53,058$ & $\$ 39,196$ & $57 \%$ & $77 \%$ \\
\hline \multicolumn{6}{|c|}{ Near Poverty } \\
\hline Women & $\$ 10,423$ & $\$ 20,576$ & $\$ 12,498$ & $51 \%$ & $83 \%$ \\
\hline Men & $\$ 12,713$ & $\$ 31,356$ & $\$ 19,765$ & $41 \%$ & $64 \%$ \\
\hline \multicolumn{6}{|l|}{ In Poverty } \\
\hline Women & $\$ 6,267$ & $\$ 16,830$ & $\$ 9,389$ & $37 \%$ & $67 \%$ \\
\hline Men & $\$ 7,763$ & $\$ 22,947$ & $\$ 13,251$ & $34 \%$ & $59 \%$ \\
\hline \multicolumn{6}{|l|}{1991} \\
\hline \multicolumn{6}{|c|}{ Above Poverty } \\
\hline Women & $\$ 23,958$ & $\$ 35,673$ & $\$ 26,071$ & $67 \%$ & $92 \%$ \\
\hline Men & $\$ 26,806$ & $\$ 48,804$ & $\$ 35,154$ & $55 \%$ & $76 \%$ \\
\hline \multicolumn{6}{|c|}{ Near Poverty } \\
\hline Women & $\$ 9,469$ & $\$ 20,026$ & $\$ 11,928$ & $47 \%$ & $79 \%$ \\
\hline Men & $\$ 11,361$ & $\$ 29,149$ & $\$ 17,750$ & $39 \%$ & $64 \%$ \\
\hline \multicolumn{6}{|l|}{ In Poverty } \\
\hline Women & $\$ 5,974$ & $\$ 16,428$ & $\$ 9,126$ & $36 \%$ & $65 \%$ \\
\hline Men & $\$ 7,465$ & $\$ 22,516$ & $\$ 12,720$ & $33 \%$ & $59 \%$ \\
\hline
\end{tabular}

Notes: Table includes survivors to 1991 only. Figures in 1994 dollars. Near poverty is between 1.0 and 1.5 times the poverty threshold. 
Replacement rates are shown for the families of disabled women and men whose actual incomes led them to be classified as poor, near poor, and nonpoor.

Our first estimated replacement rate assumes that the potential (without impairment) earnings of the disabled person is equal to the maximum covered annual earnings (in 1994 dollars) ever recorded for the individual. For a population whose average earnings would reflect the gradual deterioration of earnings capacity, we argue that this is the best measure of "disability free" earnings. This potential earnings value is then added to the remaining income of the family, and this summed value is taken as an estimate of family income had the person not become disabled. The ratio of the family's actual income (including the receipt of SSDI benefits) to this potential income value yields a "replacement rate" that reflects the effect of SSDI benefits in maintaining the family's income.

Our second estimated replacement rate assumes that the potential (without impairment) earnings of the disabled person equal the average value of the person's covered earnings during the years worked. ${ }^{22}$ This value is then added to the family's other income, and the ratio of the family's actual income to this potential income level is taken as an indicator of the income support role of SSDI benefits. Because this second estimate of potential family income is lower than that of the first, the "replacement rate" based on it will be higher. These two rates, then, yield a range of reasonable estimates of the income support effect of Social Security benefits. ${ }^{23}$

An example will clarify this calculation. Consider the average disabled woman whose actual income is below the poverty line. Our NBS data reveals that the average family income for this group of

\footnotetext{
${ }^{22}$ This average is only over the years worked and will be higher than the average earnings used to calculate SSDI benefits for those disabled workers with some years in which no earnings were reported.

${ }^{23}$ Both of these estimates are based on the actual prior earnings of disabled persons now receiving SSDI benefits. Alternatively, we could have compared the earnings potential of the disabled person, given their human capital characteristics, with the value of Social Security benefits received. However, to the extent that the onset of a disabling condition is preceded by a period of deteriorating health and work capacity that is not reflected in the potential earnings estimate, this approach would overestimate the individual's true earnings potential. Our approaches reflect this potential predisability deterioration in productivity, though in quite different ways.
} 
women was \$6,267 in 1982 (line 5, Table 7). Had these women received no benefits from Social Security, but had instead earned an amount equal to the maximum of their covered earnings, the average income of their families would have been $\$ 16,830$. The ratio of these two values yields a replacement rate of 37 percent. Alternatively, if their earnings potential had been taken as the average of their covered earnings, the average income of their families would have been $\$ 9,389$, implying a replacement rate of 67 percent.

There are several interesting patterns in this table. First, families of disabled women would have substantially lower potential incomes than families of disabled men, a reflection of labor market earning differentials. Second, the ratio of female to male actual incomes is substantially higher than is the ratio of potential incomes, reflecting the benefit formula that replaces a higher percentage of earnings of low than of high earners. This is true for individuals with actual incomes both above and below the poverty line.

Third, despite the progressive benefit formula, women and men in poverty have a smaller proportion of their potential nondisability income replaced than do those with actual incomes above the poverty line. This lower "replacement rate" among the poor would result even in the presence of a progressive benefit formula, if poor women have more sporadic work careers than do the nonpoor. Zero years of earnings will reduce the average covered earnings upon which SSDI benefits are based, resulting in a smaller ratio of SSDI benefits to actual earnings. In addition, if Social Security benefits are a small proportion of income for families with income from other sources (e.g., private disability pensions, assets, and spousal income), the effect of Social Security on this ratio will be smaller.

Finally, the difference between replacement rates using maximum and average earnings in calculating potential income is far greater for poor and near-poor disabled than for the nonpoor. This 
pattern suggests a larger and earlier effect on predisability work and earnings among the poor and near poor from the work-limiting health problems that ultimately result in their SSDI eligibility. ${ }^{24}$

\section{SUMMARY AND CONCLUSIONS}

We have provided a detailed assessment of the intertemporal economic well-being of a representative sample of new SSDI female beneficiaries, and have compared their circumstances to both disabled men and their nondisabled (though Social-Security-eligible) peers. In 1982, recently disabled working-age women receiving SSDI were a relatively poor segment of U.S. society. One quarter of them lived in poverty, and 48 percent had incomes below 150 percent of the poverty line. Over the subsequent decade, some of those married in 1982 lost husbands and the income contributed by their husbands. The transfer income that they received (primarily SSDI benefits) remained constant over the period, and provided a reliable base of income support. Yet, as of 1991, over one-half of these disabled women lived in families in which income was below 150 percent of the poverty line. On average the income of these women with disabilities was but 60 percent of a matched group of women who were not disabled.

The characteristics of the worst off among these women with disabilities provides some insight into the source of their economic disadvantages. Being young (less than 35 years of age at the time of applying for SSDI benefits) is positively and significantly related to having family income below the near-poor threshold, as is being unmarried, having children (under 18) living in the family, being nonwhite, having low levels of schooling, and living in the South.

\footnotetext{
${ }^{24}$ Disabled persons in the poverty group tend to have a higher number of zero earning years that constitute some proportion of their covered earnings records. As a result, the SSDI benefits received are diminished, as is the replacement rate. This is disguised in the replacement rate calculation based on maximum earnings. For example, compare the difference in potential earnings of women actually in poverty using the average $(\$ 9,389)$ and the maximum $(\$ 16,830)$ predisability earnings estimates. The effect on predisability earnings of the ultimate onset of disability has been studied in Livermore (1994).
} 
Our findings are consistent with other cross-sectional studies of the risk factors that compound the income effects of a disability (Ycas, 1986; Kearney et al., 1995). Our study, by comparing the disabled with a matched nondisabled sample, finds that the disabled face far higher chances of being poor than do the nondisabled. The age pattern carries two implications. First, it suggests that the progressive benefit formula of Social Security reduces the probability of being in poverty among all older "new" disabled SSDI recipients. It also implies that long-term disabling conditions prohibit younger disabled workers from enjoying the experience-related earnings available to both the nondisabled and those whose disabilities occur late in the working life. Hence, recipients who enter the SSDI rolls at an early age are disadvantaged both by their impairment and by the onset of their disability prior to the receipt of higher earnings associated with experience and age.

Disabled women who are married tend to have a lower probability of being in poverty than do those who are single, irrespective of whether they were married prior to becoming disabled or after the onset of disability. This implies that husbands of disabled women contribute more to family income than they do to the income needs of the family. However, as a percentage of family income, the contributions of the husbands of the "matched" nondisabled women are at about the same level as those of the spouses of disabled women, suggesting that having a disabled wife does not generate increased work and earnings by spouses in order to compensate for her earnings loss. Changes in marital status have an important effect on the trend in economic status over time. While moving from being married to being single increases the probability of poverty in the latter year (though the marginal risk is half that for those who were single throughout the period), becoming married later in life is associated with a risk of being poor that is identical to that for women who were married throughout the period.

Disabled men receiving SSDI benefits first in 1982 fared somewhat better economically than women, though both are clearly economically disadvantaged groups. While the poverty plus near-poverty rate is very high for both groups, it fell over time for disabled men, while it rose for disabled women. 
Over time, Social Security benefits to disabled women have played an important, and growing, role in sustaining economic status. Nevertheless, both absolutely and relative to both male disabled and female nondisabled counterparts, women with disabilities are a seriously disadvantaged group.

Consider, first, the status of disabled women relative to the comparison of nondisabled women. Prior to the first interview (and, hence, before receipt of SSDI benefits), disabled women had almost completely withdrawn from the labor force. At that point, they had neither earnings nor SSDI benefits, though subsequently disability benefits did replace some of the lost earnings. The nondisabled sample of women began their labor force withdrawal later, largely as they retired from jobs because of age eligibility. At that point, their earnings fell, and were in part replaced by earnings-related retirement benefits. Because the replacement is partial, poverty rates for this nondisabled group of females also rose over time, although they never attain the 50 percent of poverty or near-poverty rates experienced by disabled women. For these nondisabled women, then, longer work careers result in earnings and earnings-based retirement income that remain relatively high. Conversely, the persistently low level of economic status of disabled women is attributable to the low labor market earnings accompanying early labor force withdrawal, and this adverse effect stays with them throughout their lifetime.

Disabled women also fare poorly when compared to disabled men. Disabled women are less likely to be married than disabled men, hence less likely to have spousal income contributions to the family. In addition, when married, it appears that the lower earnings potential of disabled women is not compensated for by higher earnings from husbands. Moreover, because disabled men have higher earnings during their working lives than do disabled women, their SSDI benefit levels exceed those of women after the onset of disability. Again, the low labor market earnings of women prior to the onset of disability, plus their early labor force withdrawal, plagues them throughout their remaining lifetime.

These results have important policy implications, especially for those disabled women with the lowest levels of predisability earnings. On the one hand it appears that a relatively modest increase in 
aggregate Social Security benefits could eliminate poverty among disabled women and men. On the other hand, for these women and men, the replacement of nondisability earnings by SSDI based on average earnings is quite low, especially for those who are poor. Those disabled women who are married do have their well-being supported by the income contributions of spouses, but this spousal contribution is no greater percentage of total family income than it is for nondisabled women. The worst burden is borne by unmarried disabled women, who experience the combination of both the low replacement rate and the absence of spousal income.

Our findings then suggest several areas in which Social Security could assume a larger antipoverty role. Poor disabled women are disadvantaged by low education, low rates of marriage, and relatively low lifetime earnings. This makes them most likely to be dependent on SSDI benefits, both when they first become disabled and as they age into retirement years. In addition, disabled women and men are disadvantaged by a benefit formula that bases benefits on average earnings over a fixed number of years, even if earnings may have already ceased or been lowered by disability. This may be one reason why, among the poorest SSDI recipients and despite the progressive benefit formula, postdisability income is a lower percentage of predisability income than it is among the nonpoor. Raising the first bend point (the dollar value at which the replacement multiplier changes from .90 to .32 ), or reintroducing a minimum benefit level, would have a substantial effect on the economic well-being of these most vulnerable of OASDI beneficiaries.

Second, some groups of disabled—particularly the very young and those who are unmarried (both those who are single and those who become single through divorce or widowhood) —appear especially vulnerable to falling into poverty. The very young among the disabled may be disadvantaged by a formula that ignores the forgone potential growth in future earnings, suggesting clear benefits to them of a policy change that would constrain the number of years of zero earnings that are counted in the formula determining SSDI benefits. 
Finally, although disabled women who move into retirement years tend to have levels of wellbeing that are closer to those of nondisabled retired workers, this convergence is due to the retirement of the nondisabled group and not to increased well-being of the disabled women. Indeed, over time the absolute levels of economic well-being of disabled women (although not of men) continue to erode. It follows that, for the low-income group of disabled women (and men), downward adjustments in the CPIbased benefit formula (or in the formula itself) would extract a high price in terms of economic destitution and security. 


\section{APPENDIX I Creation of the Matched SSDI-Eligible Nondisabled Sample}

The matched SSDI-eligible nondisabled sample was created to provide a nondisabled group of workers to compare to the NBS sample of disabled workers. The creation of the matched sample began with a raw PSID extract of 9,117 individuals aged 20 to 65 in 1980. After removing disabled individuals from the PSID sample, remaining individuals were passed through an SSDI-eligibility screen in order to select only workers with enough work history to be eligible for SSDI in the event of disability. This is the appropriate comparison group for individuals in the NBS, all of whom meet SSDI eligibility criteria by definition. Once the SSDI-eligible group of nondisabled workers was identified, weights were applied to match the NBS joint distribution of age, education, sex, race and marital status. By matching, we are assured that differences in economic well-being across the two samples are not driven by differences in these demographic variables.

Disabled individuals were identified in the PSID by using both self-reported health status and program participation information. Heads of household who reported their health status as "disabled" and who indicated that their disability reduced the amount of work they could do "a lot" were identified as disabled. In addition, all individuals who reported their employment status as "permanently disabled," all individuals under 59 who received Social Security benefits, and all individuals who received Supplemental Security Income (SSI) or Workers' Compensation were identified as disabled and removed from the sample.

To condition the nondisabled sample on SSDI eligibility, work histories from 1968 to 1980 were extracted from previous waves of the PSID. Eligibility for SSDI is determined by counting "quarters of credit." Since the PSID is an annual data set, we approximated this with similarly defined "years of credit." An individual obtains a year of credit if he or she has sufficient annual earnings. The annual earnings requirements were $\$ 1000$ from 1968 to $1978, \$ 1040$ in 1979 , and $\$ 1160$ in 1980 . To be eligible 
for SSDI, an individual must have five years of credit out of the last ten years. For workers under 31 years of age, eligibility requires 1.5 years of credit out of the last three years. Only workers who met the eligibility criteria in 1980 were selected for the matched nondisabled sample.

The two samples were matched nonparametrically. Each sample was subdivided into 192 cells, each cell representing a particular combination of age, education, sex, race, and marital status. The possible values of the demographic characteristics were defined as follows:

Age (6 bins): 20-34, 35-51, 52-54, 55-58, 59-61, 62-65

Education (4 bins): <HS, some HS, HS grad, >HS

Sex (2 bins): women, men

Race (2 bins): white, nonwhite

Marital status (2 bins): married, single

The age bins were chosen to reflect similar cohorts with regard to Social Security eligibility over the 1982-1991 time period. Matching was accomplished by creating a matching weight for each of the 192 bins. The matching weight was defined as the cell frequency in the NBS divided by the corresponding cell frequency in the PSID. Weighting each observation in the PSID sample by the appropriate matching weight created a sample with the same joint distribution of demographics as the NBS. Tabulations of demographics confirm that the two samples are now matched. The matched SSDI-eligible nondisabled sample has 6242 observations in 1982 and 4961 in 1991. 


\section{APPENDIX II Income Measures in the NBS}

The family income measures used in this study include only the income of the respondent, spouse if married, and of any children under 18. The 1991 resurvey did not ask about the income of other household members, even if related to the respondent. Thus, while we know if other household members are present, we do not know their income. Hence even though total family and household income for 1982 in the NBS and for both years of the PSID are known, comparative changes in these broader income measures over time among the disabled cannot be studied. Appendix Table 1 shows 1982 poverty incidence using both household and "nuclear" family income measures. In the household calculation, the income of all householders is included and the needs of the household reflect the total number in the household. The analogous values for the family exclude both the income and those living in the household who are not part of the nuclear family. Poverty incidence remains virtually the same for both men and women under either measure.

Despite this relative stability in poverty incidence, the contribution and needs of a substantial percentage of households are not fully taken into account. About one-third of the 1982 disabled women had another adult (who could have been a child over 18) in addition to their spouse in the household. This was true of almost 42 percent of households in 1991, a result we suspect of children present in 1982 growing older. Indeed, 35 percent of these other adults in the families of disabled women were children between 18 and 30, and 15 percent were children 30 to 50, while in 199116 percent and 34 percent were in these age groups, respectively. To the extent that these older children would add more to the needs of the household than to the household's income, by adopting a nuclear family income measure we would overstate the income-to-needs ratio and underestimate poverty. However, on average they appear to contribute an amount to family income which is about equal to their consumption "needs." 
In essence, then, one question being addressed in the study is: To what extent does the Social Security system provide income security to individuals and couples (and their minor children) who lose earnings through disability or retirement? Because OASDI benefits are provided only to retired and disabled workers, their spouses, and minor children, our exclusion of other adult household members is consistent with program rules, and does not affect the policy relevance of our findings. Even if other related adults either help compensate for the income decline experienced by the respondent and spouse or place an added economic burden on the family, such interfamily decisions are outside the policy focus of SSDI. 
APPENDIX II, TABLE 1

Comparison of Poverty Rates Using Different Definitions of Consumption Unit: NBS Disabled, 1982

\begin{tabular}{|c|c|c|c|c|}
\hline \multirow[b]{2}{*}{ Household Poverty } & \multicolumn{4}{|c|}{ Family Poverty } \\
\hline & Not Poor & Near Poor & Poor & Total \\
\hline \multicolumn{5}{|l|}{ Females } \\
\hline Not Poor & 46.3 & 3.0 & 1.5 & 52.8 \\
\hline Near Poor & 3.0 & 16.6 & 1.7 & 21.4 \\
\hline Poor & 1.0 & 3.2 & 21.8 & 25.9 \\
\hline Total & 52.3 & 22.7 & 25.0 & 100.0 \\
\hline \multicolumn{5}{|l|}{ Males } \\
\hline Not Poor & 54.2 & 2.3 & 1.2 & 57.8 \\
\hline Near Poor & 2.8 & 15.9 & 1.8 & 20.5 \\
\hline Poor & 0.6 & 3.3 & 17.9 & 21.8 \\
\hline Total & 57.6 & 21.5 & 20.9 & 100.0 \\
\hline
\end{tabular}




\section{References}

Blau, Francine D., and Marianne Ferber. 1986. The Economics of Women, Men and Work. Englewood Cliffs, N.J.: Prentice-Hall, Simon \& Schuster, Inc.

Buckley, John. 1971. "Pay Differences between Men and Women in the Same Job." Monthly Labor Review 94 (11): 36-39.

Danziger, Sheldon H., and Daniel H. Weinberg. 1994. "The Historical Record: Trends in Family Income, Inequality, and Poverty.” In Confronting Poverty: Prescriptions for Change, ed. Sheldon H. Danziger, Gary D. Sandefur and Daniel H. Weinberg. Cambridge, Mass.: Harvard University Press.

Groshen, Erica L. 1991. "The Structure of the Female/Male Wage Differential.” Journal of Human Resources 26 (3): 457-472.

Hennessey, John C., and Janice M. Dykacz. 1989. "Projected Outcomes and Length of Time in Disability Insurance Program.” Social Security Bulletin 52 (9): 2-41.

Hennessey, John C., and Janice M. Dykacz. 1993. "A Comparison of the Recovery Termination Rates of Disabled-Worker Beneficiaries Entitled in 1972 and 1985." Social Security Bulletin 56 (2): 58-69.

Hennessey, John C., and Scott Muller. 1994. "Work Efforts of Disabled-Worker Beneficiaries:

Preliminary Findings from the New Beneficiary Survey." Social Security Bulletin 57 (3): 42-51.

Kearney, John R., Herman F. Grundmann, and Salvatore J. Gallicchio. 1995. "The Influence of the OASDI and SSI Payments on the Poverty Status of Families with Children." Social Security Bulletin 58 (3): 3-14.

Livermore, Gina. 1994. "The Effects of Predisability Poor Health on Earnings, Equity, and Economic Well-Being of Men with Disabilities." University of Wisconsin-Madison, Department of Economics, Ph.D. dissertation.

Mashaw, Jerry L., and Virginia Reno. 1996. “Overview.” In Jerry L. Mashaw, Virginia Reno, Richard V. Burkhauser, and Monroe Berkowitz, Disability, Work and Cash Benefits. Kalamazoo, Mich.: W. E. Upjohn Institute for Employment Research.

Muller, L. Scott. 1992. "Disability Beneficiaries Who Work and Their Experience under Program Work Incentives.” Social Security Bulletin 55 (2): 2-19.

Rupp, Kalman, and David Stapleton. 1995. "Determinants of the Growth in the Social Security Administration's Disability Programs-An Overview.” Social Security Bulletin 58 (4): 43-70.

Social Security Administration. 1993. "Statistical Notes from the New Beneficiary Data System." Social Security Bulletin 56 (3): 88-94. 
Social Security Administration. 1996. Annual Statistical Supplement to the Social Security Bulletin: 1996. Washington, D.C.: Office of Research and Statistics, Social Security Administration.

Ycas, Martynas A. 1986. "Asset Holdings of the Newly Disabled: Findings from the New Beneficiary Survey." Social Security Bulletin 49 (12): 5-12.

Ycas, Martynas A. 1992. “A New Beneficiary Data System: The First Phase.” Social Security Bulletin 55 (2): 20-35. 